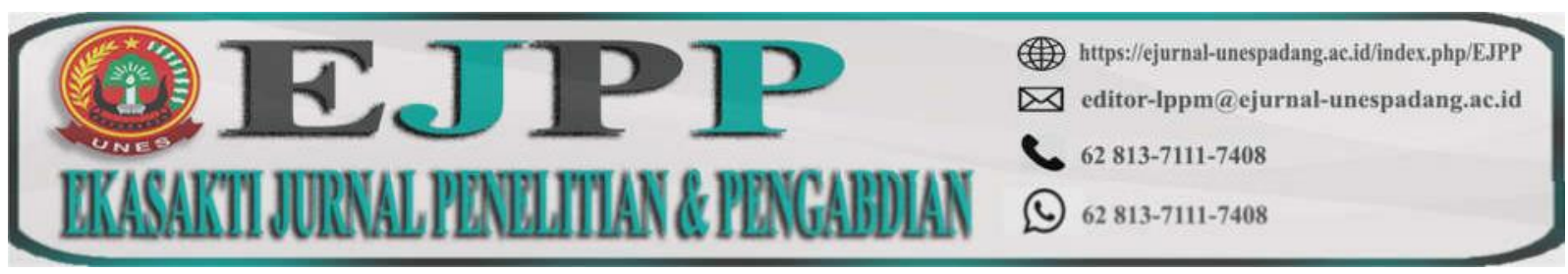

DOI: https://doi.org/10.31933/ejpp.v1i1

Received: 01/11/2020, Revised: 12/11/2020, Publish: 22/11/202

\title{
PENINGKATAN PENDAPATAN RUMAH TANGGA PETANI DENGAN TANAMAN PEKARANGAN “KUJARAI” DI LUBUK PANDAN
}

\author{
Syamsuwirman ${ }^{1}$, Yonny Arita Taher ${ }^{2}$, Herda Gusvita ${ }^{3}$ \\ 1) Fakultas Pertanian, Universitas Ekasakti Padang \\ E-mail: syamsuwirman234@yahoo.co.id \\ 2) Fakultas Pertanian, Universitas Ekasakti Padang \\ E-mail: yonnyarita11@gmail.com \\ 3) Fakultas Pertanian, Universitas Ekasakti Padang \\ E-mail: herda.gusvita@yahoo.com
}

\begin{abstract}
ABSTRAK
Nagari Lubuk Pandan termasuk daerah pertanian yang mempunyai potensi jerami. Potensi tersebut belum dimanfaatkan oleh petani, padahal jerami dapat menyediakan hara dan bahan organik tanah. Persoalan petani adalah kurangnya akses terhadap sarana produksi seperti pupuk an-organik. Berdasarkan hal tersebut telah dilakukan sebuah kegiatan untuk membantu petani memproduksi pupuk organik dan mengaplikasikannya ke tanaman pekarangan, yang dapat meningkatkan pendapatan. Tujuan kegiatan secara umum untuk meningkatkan pendapatan petani dengan memproduksi pupuk organik yang digunakan untuk tanaman "kujarai" (kunyit, jahe, serai). Kegiatan direncanakan akan dilaksanakan oleh mahasiswa KKN setelah proposal diterima oleh Kemenristek, tertanggal 28 Januari 2020. Namun dikarenakan pandemi Covid-19 yang terjadi pada tahun 2020 munculnya larangan berkumpul yang juga berdampak pada berubahnya sistem KKN pada mahasiswa yang akan melaksanakan kegiatan KKN. Akhirnya mahasiswa melaksanakan kegiatan disekitar tempat tinggal atau daerah asalnya. Selanjutnya kegiatan diperluas dari awalnya Nagari Lubuk Pandan, menjadi Kabupaten Padang Pariaman. Teknis pelaksanaan, pertama didata mahasiswa yang bertempat tinggal di Kabupaten Padang Pariaman, dengan 30 orang mahasiswa yang melaksanakan kegiatan. Masing-masing mahasiswa peserta membina dan melakukan penanaman "Kujarai" di pekarangan sebanyak 10 keluarga. Dari kegiatan yang telah dilaksanakan, diperkirakan masing-masing petani mendapatkan peningkatan pendapatan 6 -7 bulan ke depan, Rp. 294.000 dari kunyit, Rp. 1.350.000,- dari jahe, dan Rp. 400.000,- dari serai, dengan total pendapatan Rp. 2.044.000,-. Target untuk kegiatan ini adalah petani mampu membuat pupuk organik dari limbah pertanian dan mengaplikasikannya ke tanaman, memaksimalkan pekarangan untuk meningkatkan pendapatan masyarakat.
\end{abstract}


Kata Kunci : Pupuk organik, tanaman pekarangan, kunyit, jahe, serai.

\begin{abstract}
Nagari Lubuk Pandan is an agricultural area tha has the potential for hay. This potential has not been exploited by farmers, even though hay can provide nutrients and soil organic matter. The farmers' problem is the lack of access to production facilities such as in-organic fertilizers. Based on this problem, there has been activity that help farmers produce organic fertilizers and apply it to their home gardens, which can increase their income. The aim of the activity in general is to increase farmers' income by producing organic fertilizers used for "kujarai" crops (turmeric, ginger, lemongrass). The activity is planned to be carried out by KKN students after the proposal is accepted by the Ministry of Research and Technology, dated January 28, 2020. However, due to the Covid-19 pandemic that occurred in 2020, there is a ban on gathering which also has an impact on changing the KKN system. Therefore, students carry out activities around their home or origin. Furthermor, the activity was expanded from Nagari Lubuk Pandan to Padang Pariaman District. The technical implementation, first, record data on students who live in Padang Pariaman Regency, with 30 students who carry out the activity. Each student fostered and planted "Kujarai" in the yard of 10 families. From the activities that have been carried out, it is estimated that each farmer will get an increase in income in the next 6-7 month. The target for this activity is that farmers are able to make organic fertilizer from agricultural waste and apply it to crops, maximizing their yards to increase community income.
\end{abstract}

Keywords: Organic fertilizer, garden plants, turmenic, ginger, lemongrass.

\title{
PENDAHULUAN
}

Ekstensifikasi semakin sulit dilakukan karena semakin terbatasnya ketersediaan lahan untuk usahatani. Oleh karena itu, intensifikasi melalui diversifikasi pertanian akan sangat membantu peningkatan produktivitas, tanpa merusak lingkungan. Pemanfaatan lahan pekarangan perlu menjadi perhatian, terutama untuk pengembangan buah-buahan berumur panjang. Sasaran pengembangan buah-buahan pada lahan pekarangan adalah: (i) membangun kawasan agribisnis buah-buahan pada suatu kawasan potensial, dan (ii) mendukung ketahanan pangan keluarga di pedesaan. Buah-buahan yang menjadi fokus pengembangan oleh Dinas Pertanian Provinsi Sumatera Barat adalah jeruk, pisang, dan manggis (Dipertahor, 2007). Dalam pola pangan harapan (PPH) Departemen Pertanian, sumber energi dari buah-buahan diharapkan mencapai $3 \%$, sementara dari gula hanya 5\%. Hal ini menunjukkan potensi konsumsi buah masyarakat meningkat (Pusbang Ketersediaan Pangan, 2005).

Berbagai kemajuan telah dicapai dalam pembangunan pertanian di Sumatera Barat. Indikator pembangunan pertanian tersebut di antaranya: (i) Peningkatan intensitas pertanaman

yang berdampak pada surplus beras dan peningkatan areal tanaman perkebunan unggulan; (ii) Perbaikan mutu sayuran, terbangunnya kawasan pertanian organik; (iii) Peningkatan populasi ternak; (iv) Ekspor produk pertanian mulai membaik; serta (v) Mulai berkembang dan 
membaiknya kelembagaan petani dan infrastruktur pertanian. Pembangunan pertanian tersebut telah meningkatkan kontribusi sektor pertanian dalam PDRB Sumatera Barat dari tahun ke tahun. Pada tahun 2006, sumbangan sektor pertanian terhadap PDRB mencapai 25,26\% (Bappeda Sumatera Barat, 2007). Kabupaten Padang Pariaman memiliki luas total sebesar 132.879 hektare (ha). Berdasarkan penggunaan lahan, maka sebagian besar luas lahan di Kabupaten Padang Pariaman pada tahun 2018 terdiri dari lahan pertanian bukan sawah, yaitu seluas 77.946 ha, lahan bukan pertanian seluas 32.077 ha, dan yang merupakan lahan sawah seluas $22.856 \mathrm{ha}$.

Dengan begitu luasnya sawah di Kabupaten ini, maka potensi jerami yang dihasilkan untuk 1 kali musim padi dapat dihitung sebagai berikut : Menurut Kim dan Dale (2004) potensi jerami kurang lebih 1,4 kali dari hasil panen. Rata-rata produktivitas padi nasional adalah 4,895ton/ha, sehingga jumlah jerami yang dihasilkan kurang lebih 6,853 ton/ha. Luas sawah di Kabupaten Padang Pariaman adalah $22.856 \mathrm{Ha}$, dengan demikian potensi jerami adalah 156.632,17 ton. Potensi jerami yang sangat besar ini sebagian besar masih disia-siakan oleh petani.Pemanfaatan jerami dalam kaitannya untuk menyediakan hara dan bahan organik tanah adalah merombaknya menjadi pupuk organik/kompos. Rendemen kompos yang dibuat dari jerami kurang lebih $60 \%$ dari bobot awal jerami, sehingga pupuk organik jerami yang bisa dihasilkan dalam satu ha lahan sawah adalah sebesar 4,11 ton/ha. Jika semua jerami di kabupaten ini dibuat menjadi pupuk organik akan dihasilkan sebanyak 93.938,16 ton.

Dari hasil penelitian Syamsuwirman (2011) yang menghasilkan pupuk organik limbah pertanian dengan kadar unsur Nitrogen $(\mathrm{N})$ sebesar 3,41\%, maka untuk 1 Ha sawah membutuhkan pupuk organik sebanyak 2,6 ton/ha. Artinya apabila seluruh potensi jerami tidak di bakar, atau dibuat menjadi pupuk organik, maka petani tidak memerlukan pasokan pupuk lainnya dari luar. Selanjutnya apabila ini dapat dilakukan pembuatan pupuk organik disamping menjaga lingkungan dari pencemaran, sekaligus nantinya akan meningkatkan kualitas produksi padi yang dihasilkan. Malahan kalau ini dapat dimanfaatkan petani sebagai produsen pupuk organik dapat memperoleh tambahan penghasilan dari penjualan pupuk organik yang dihasilkan.

Kebutuhan pupuk organik untuk sawah yang ada semakin lama akan semakin meningkat, sedangkan apabila semua jerami yang dihasilkan dibuat menjadi pupuk organik akan menghasilkan pupuk organik yang melebihi kebutuhan. Kelebihan produksi pupuk organik apabila diaplikasikan kepada tanaman pekarangan, buah-buahan, maka untuk tahun-tahun berikutnya berkemungkinan besar akan terjadi peningkatan terhadap produksi tanaman pertanian yang ada di Kabupaten Padang Pariaman.

Pemberdayaan tidak hanya masalah pembangkitan kesadaran, tetapi juga upaya mengubah keadaan kehidupan material orang-orang yang tertindas dan lemah dalam masyarakat. Kajian teori yang berhubungan dengan pemberdayaan (Mas'ud, 2002) upaya untuk memperkuat posisi seseorang melalui penumbuhan kesadaran dan kemampuan individu. Untuk mengidentifikasi persoalan yang dihadapi dan memikirkan langkah-langkah untuk mengatasinya. Menurut Tjandraningsih (1995), merupakan suatu proses perubahan dari ketergantungan kepada 
kemandirian, melalui perwujudan kemampuan yang dimiliki. Menurut Sumodiningrat (1999) usaha pemberdayaan didasari filsafat tentang akan hak dan kewajiban manusia, serta adanya anggapan bahwa manusia mempunyai potensi atau kemampuan daya yang dapat dikembangkan.

Tujuan pemberdayaan adalah: (1) Agar individu memiliki keberdayaan, yaitu kemampuan individu untuk membangun diri agar sehat fisik, mental, terdidik, kuat, memiliki nilai-nilai yang instrinsik yang menjadi sumber keberdayaan. (2) Agar individu dapat bertahan (survive) dalam pengertian yang dinamis, mengembangkan diri dan meningkatkan harkat dan martabat manusia. (3) Meningkatkan kemampuan dan kemandirian manusia. Untuk mencapai keberdayaan dapat diupayakan dengan: (1). Menciptakan iklim/suasana yang memungkinkan potensinya berkembang. (2). Memperkuat potensi yang dimiliki. (3). Melindungi, mencegah yang lemah menjadi semakin lemah. (4). Melalui latihan praktek secara langsung melalui proses belajar.

Dalam kegiatan KKN-PPM ini cara yang dilakukan untuk memberdayakan petani padi adalah transfer ilmu dan teknologi dengan "learning by doing" yaitu dengan membimbing petani dengan kegiatan pelatihan dan praktek pembuatan pupuk dan pengurai, serta aplikasinya dalam bentuk pengaplikasian pupuk dan penanaman kunyit, jahe, serai.

Definisi pekarangan dijelaskan oleh Wurianingsih (2011) bahwa pekarangan adalah taman rumah tradisional yang bersifat pribadi, yang merupakan sistem yang terintegrasi dengan hubungan yang erat antara manusia, tanaman, dan hewan. Menurut Ninez dalam Galhena dkk. (2013) lahan pekarangan adalah suatu lahan yang terletak dekat dengan tempat tinggal yang memiliki keamanan, kenyamanan dan membutuhkan perawatan khusus serta dapat melaksanakan suatu sistem penyediaan tanaman dan hewan dalam skala kecil sehingga dapat dikonsumsi oleh anggota rumah tangga. Pemanfaatan lahan pekarangan memiliki fungsi yang dapat berguna bagi yaitu: (a) untuk memenuhi kebutuhan gizi dari rumah tangga, sehingga rumah tangga bisa mengkonsumsi makanan yang sehat, (b) meningkatkan pendapatan, (c) menambah lapangan kerja, (d) meningkatkan peran dalam memproduksi tanaman pekarangan, (e) bermanfaat dalam menjaga kelestarian lingkungan, (f) pekarangan sebagai penyedia bahan bangunan dan kayu bakar.

Pekarangan sering disebut dengan istilah "apotek hidup,"warung hidup atau sebagai "lumbung hidup" sesuai dengan berbagai fungsi lahan pekarangan tersebut. Pada pekarangan itu sendiri terdapat beraneka tanaman yang dapat dimanfaatkan untuk memenuhi kebutuhan dan dapat juga menambah pendapatan penghuninya. Sebagai contoh tanaman umbi-umbian antara lain ubi kayu, ubi jalar, talas dapat digunakan sebagai pengganti makanan pokok seperti beras dan dapat juga menambah pendapatan rumah tangga petani. Peran tersebut semakin berarti ketika terjadi kegagalan panen akibat serangan hama atau hal lainnya. Tanaman pekarangan dapat digunakan sebagai sayuran, bumbu, obat-obatan, atau kayu bakar. Hal-hal tersebut menggambarkan fungsi subsistem dari pekarangan (Balitbang Pertanian, 2010).

Adapun tujuan yang hendak dicapai adalah : memasyarakatkan pembuatan pupuk organik dari sampah pertanian untuk dipergunakan sendiri; memaksimalkan potensi pekarangan yang ada di rumah tangga petani; dengan adanya tanaman di pekarangan petani, diharapkan akan 
meningkatkan pendapatan keluarga petani itu sendiri; adanya efek domino dari keluarga yang melaksanakan kegiatan terhadap keluarga lain, atau tetangga karena pada umunya masyarakat petani mempunyai sifat "meniru". Sebagai sasaran kegiatan adalah keluarga petani yang pekarangan masih belum termanfaatkan.

\section{METODE PENELITIAN}

Didata mahasiswa yang berada di Padang-Pariaman sebanyak 30 orang. Rekruitmen mahasiswa: Mahasiswa yang akan diikutkan dalam kegiatan KKN-PPM ini memiliki kriteria sebagai berikut: Semester VI ke atas terutama dari Fakultas Pertanian; Mau bekerjasama dengan petani; Bersedia mengikuti pelatihan sebelum turun ke lokasi. Mahasiswa melaksanakan kegiatan penanaman di sekitar tempat tinggal atau daerah terpilih.

Mahasiswa mencari keluarga (10 keluarga masing-masing) yang bersedia untuk melakukan kegiatan penanaman 3 jenis tanaman di pekaranganya yaitu Kunyit, Jahe, dan Serai. Masingmasing tanaman 10 rumpun. Dalam kegiatan melibatkan 300 keluarga (menanam 3000 kunyit, jahe, dan serai). Kecamatan dan Nagari serta mahasiswa yang melaksanakan kegiatan adalah: Nan Sabaris, Lubuk Alung, Ulakan Tapakis, dan Batang Anai. Setelah didapatkan keluarga yang bersedia, mahasiswa melakukan pengolahan lahan dan menaburkan pupuk organik.

Sebelum dilakukan pengolahan lahan pupuk organik di distribusikan ke tempat kegiatan masing-masing keluarga 1 karung (pupuk sudah diproduksi bersama mahasiswa setelah adanya kepastian proposal kegiatan diterima). Setelah pengolahan lahan, tanah diinkubasi 10 - 12 hari dengan menutup menggunakan karung bekas. Setelah inkubasi, dilakukan penanaman dengan jarak tanam:

1. Kunyit $: 50 \times 30 \mathrm{~cm}:$ butuh lahan $1 \times 1,5$ meter

2. Jahe $: 50 \times 30 \mathrm{~cm}:$ butuh lahan $1 \times 1,5$ meter

3. Serai $: 50 \times 30 \mathrm{~cm}$ : butuh lahan $1 \times 1,5$ meter

Sewaktu penanaman dilakukan kunjungan atau monitoring kegiatan. Dilakukan pengamatan terhadap perkembangan pertumbuhan tanaman. Dilakukan pengambilan gambar: pembuatan pupuk organik; pengolahan lahan; pemberian pupuk; penutupan dengan karung bekas untuk inkubasi; penanaman; dan pemeliharaan.

\section{HASIL DAN PEMBAHASAN}

Dari pelaksanaan kegiatan yang telah dilaksanakan, diperkirakan hasil produksi yang didapatkan $6-7$ bulan ke depan adalah :

Tabel 1.Perkiraan hasil produksi Tanaman KUJARAI

\begin{tabular}{clcrr}
\hline No. & & $\begin{array}{c}\text { Perkiraan Produksi } \\
(\mathbf{k g})\end{array}$ & Harga Satuan (Rp.) & Pendapatan (Rp.) \\
\hline 1. & Kunyit Rimpang & 5 & 30.000 & $150.000,-$ \\
& Daun & $250(36$ ikat $)$ & $4.000,-$ & $144.000,-$ \\
2. & Jahe Rimpang & 30 & 45.000 & 1.350 .000 \\
3. & Serai & 400 batang & $1.000,-$ & $400.000 .-$ \\
\hline & & & Total & $\mathbf{2 . 0 4 4 . 0 0 0}$ \\
\hline
\end{tabular}


Dari tabel di atas dapat dilihat peningkatan pendapatan untuk masing-masing petani, apabila dihitung produsi untuk semua yang melaksanakan, maka menghasilkan kunyit (rimpang $=1,5$ ton +10.800 ikat), jahe ( 9 ton) dan serai (120.000 batang). Dengan besarnya peningkatan pendapatan, diharapkan petaqni yang telah melaksanakan kegiatan terus melakukan penanaman 3 jenis tanaman tersebut di pekarangan, dan diharapkan juga adanya efek "domino " terhadap petani tetangganya.

\section{Keluaran Yang Dicapai}

Sebagai target luaran kegiatan antara lain :

1. Artikel ilmiah yang dipublikasikan melalui jurnal ber ISSN atau prosiding seminar nasional.

2. Artikel pada media massa cetak.

3. Video kegiatan

4. Peningkatan keberdayaan mitra dalam hal pengetahuan, ketrampilan, kesehatan, pendapatan, dan pelayanan.

\section{Manfaat Yang Diperoleh}

1. Tanaman yang ditanam dipekarangan mudah dimonitor, dan tanaman seperti kunyit, jahe, dan serai (kujarai), tidak memerlukan keahlian khusus dalam hal budidayanya.

2. Pengetahuan dan ketrampilan petani dalam memanfaatkan bahan yang dapat menjadi pengurai (dekomposer) untuk pembuatan pupuk organik sudah ada namun belum termanfaatkan karena pengaplikasiannya dianggap masih susah.

3. Pupuk organik disini adalah pupuk yang bahan bakunya jerami padi yang telah dihaluskan (25\%), pupuk kandang (50\%), abu dan sekam padi $(20 \%)$, dan dedak padi halus + kapur dolomit (5\%), serta MOL buah maja sebanyak 1 liter. Semua bahan diaduk dan fermentasi 10 - 14 hari. Sedangkan MOL buah maja adalah adalah cairan yang terbuat dari bahan-bahan alami yang disukai sebagai media hidup dan berkembang bagi mikro organisme, yang berguna untuk mempercepat penghancuran bahan-bahan organik atau dekomposer dan sebagai aktivator atau tambahan unsur hara bagi tanaman yang sengaja dikembangkan dari bahan-bahan yang tersedia di sekitar. Untuk meningkatkan unsur hara pupuk organik yang dibuat, maka MOL ditambahkan dengan urine sapi, Tithonia diversifolia, dan air cucian beras.

4. Pengembangan pengurai lokal bertujuan agar petani dapat memanfaatkan sumberdaya lokal yang cukup banyak dan belum termanfaatkan sehingga dapat mengurangi biaya produksi dan ketergantungan terhadap jenis produk tertentu.

5. Diharapkan petani yang ditanami pekarangannya dengan 3 jenis tanaman akan memberikan efek domino terhadap tetangganya, sehingga di waktu yang akan datang semakin banyak memanfaatkan pekarangan untuk membatu ekonomi keluarga. 


\section{Faktor Yang Menghambat/Kendala, Faktor Yang Mendukung Dan Tindak Lanjut}

1. Faktor penghambat/kendala

Faktor yang menghambat kegiatan adalah adanya wabah Covid-19, sehingga mahasiswa tidak leluasa dalam melakukan kegiatan, dana kegiatan yang hanya diakui $60 \%$ dari yang diajukan menyebabkan tidak leluasa untuk memperluas cakupan kegiatan. Dana yang diajukan 49 juta, sedangkan yang didanai 31 juta.

2. Faktor yang mendukung

Faktor yang mendukung, mahasiswa pelaksana kegiatan semuanya berasal dari Fakultas Pertanian, masyarakat petani yang dibina antusias, begitu juga pemerintah daerah seperti Wali Nagari, sangat mendukung kegiatan terutama untuk meningkatkan potensi pekarangan guna meningkatkan ekonomi keluarga.

3. Solusi dan tindak lanjutnya

Tindak lanjut setelah kegiatan, mahasiswa yang sudah familiar dengan masyarakat dengan dibantu dosen pelaksana kegiatan, mengunjungi lagi keluarga tempat kegiatan, agar dapat lebih dikembangkan dan memberikan efek domino kepada petani tetangga lain. Satu tahun kemudian diharapkan petani yang dibina sudah merasakan peningkatan ekonomi keluarganya.

4. Rencana selanjutnya

Bagi dosen pelaksana di tahun-tahun yang akan datang dijadikan tempat kegiatan sebagai nagari binaan untuk tempat melaksanakan kegiatan Tri Dahrma Perguruan Tinggi.

5. Langkah-langkah strategis untuk realisasi selanjutnya

Langkah-langkah strategis untuk realisasi selanjutnya, dibuat kerjasama antara Perguruan Tinggi dengan Pemerintah Daerah guna mewujudkan atau menjadikan daerah tempat kegiatan menjadi daerah binaan. Setelah adanya budidaya, untuk selanjutnya mungkin diperlukan binaan pemasaran, binaan untuk membuat aneka produk dari yang telah dihasilkan.

\section{KESIMPULAN DAN SARAN}

Dari kegiatan yang telah dilaksanakan dapat diambil beberapa kesimpulan:

1. Masih banyak potensi pertanian yang belum termanfaatkan.

2. Pekarangan rumah tinggal petani masih dapat ditanami untuk meningkatkan ekonomi keluarga.

3. Masing-masing petani mendapatkan tambahan pendapatan dalam 6-7 bulan ke depan sebanyak Rp. 2.044.000,-.

Berdasarkan kesimpulan disarankan untuk melakukan kegiatan peningkatan potensi pekarangan petani demi meningkatkan ekonomi keluarga petani. 


\section{REFERENSI}

Balitbang Pertanian. 2010. Rencana strategis Badan Penelitian dan Pengembangan Pertanian 2010 - 2014. Badan Litbang Pertanian. Jakarta. Kementrian Pertanian.

Galhena, D.H. 2013. Home Gardens ; A promising approach to enhance household food security and wellbeing. Journal agriculturale and food security, 2 (8) : $1-13$.

Kim, Seungdo and Bruce E. Dale, 2004. Global potential bioethanol production from wasted crops and crop residues. Biomass and Bioenergy, 26, pp. 361-375.

Mas'ud, Fuad. 2002. Survey diagnosis organisasional, konsep dan aplikasi. Semarang. BP Undip.

Misran, 2014. Studi Sistem Tanam Jajar Legowo terhadap Peningkatan Produktivitas Padi Sawah. Jurnal Penelitian Pertanian vol 14. BPTP Sumatera Barat.

Novia Prima, Syamsuwirman, Gusriati,. 2014. Produksi pupuk organik limbah pertanian untuk peningkatan pendapatan petani di Nagari Lubuk Pandan. Laporan Akhir KKN-PPM. Fakultas Pertanian Universitas Ekasakti Padang. 76 hal.

Novia Prima, Syamsuwirman, Amnilis. 2015. IbM Aplikasi pupuk organik limbah pertanian untuk peningkatan pendapatan petani adi di Nagari Lubuk Pandan. Laporan akhir IbM. Fakultas Pertanian Universitas Ekasakti Padang. 31 hal.

Pemerintahan nagari Lubuk Pandan. 2014. Profil Nagari Lubuk Pandan.

Sumodiningrat, Gunawan. 1999. Pemberdayaan masyarakat dan jaringan pengaman sosial. Gramedia Pustaka Utama. Jakarta.

Syamsuwirman. 2011. Inovasi teknologi pembuatan pupuk tablet dari kompos limbah organik pasar sebagai pengganti pupuk kimia di Kota Padang. Laporan pengabdian Iptekda LIPI XIV. Faklutas Pertanian Universitas Ekasakti. Padang. 51 hal.

2013. IbM produksi pupuk organik limbah pertanian. Pertanian Universitas Ekasakti. Padang. 41 hal.

2016. KKN_PPM Peningkatan produksi kakao dengan aplikasi pupuk organik limbah pertanian. Proposal KKN-PPM. Fakultas Pertanian Universitas Ekasakti. Padang. 33 hal.

Tjandraningsih, I. 1995. Pemberdayaan pekerja anak. Yayasan Akatiga. Bandung.

Wurianingsih, Mega. 2011. Studi karakteristik dan fungsi pekarangan di desa Pasir Eurih Kecamatan Taman Sari Kabupaten Bogor. Skripsi. Institut Pertanian Bogor. 